\title{
PRODUCTIVITY OF A FARM TRACTOR WITH SINGLE DRUM WINCH DURING WHOLE-TREE TIMBER EXTRACTION
}

\author{
PROIZVODNOST ADAPTIRANOG POLJOPRIVREDNOG \\ TRAKTORA S JEDNOBUBANJSKIM VITLOM TIJEKOM \\ PRIVLAČENJA DRVA STABLOVNOM METODOM
}

\section{Sercan GULCl*}

\begin{abstract}
SUMIMARY
In forested areas with difficult terrain conditions the cost of forest harvesting operations is of great importance. This situation affects the technology standards of tools and equipment used in forestry operations. Especially in developing countries modified farm tractors are widely used as effective tools for transporting timber from stump to landing areas. In this study, productivity of the farm tractor with front-mounted single drum winch designed for multipurpose use in forestry operations was evaluated during whole-tree harvesting operation. The total cost of used system (tractor and winch) is approximately $19580 €$ (Euro). Time and motion study was implemented by using repetitive time measurement technique during two step timber extraction operation. The effects of main factors such as tree diameter, height, volume, and skidding distance on the total operation time were investigated and then linear regression analysis was performed to develop the mathematical models for whole-tree extraction methods. Time study data resulted that winching trees to the prebunching area was the most time consuming work stage in uphill winching method while skidding trees backward to landing was less time consuming work stage in skidding method. The average productivity of uphill winching and skidding whole-tree was as $12.98 \mathrm{~m}^{3} /$ hour and $14.30 \mathrm{~m}^{3} /$ hour, respectively. The cost of uphill winching and skidding was $10.77 € /$ hour and $11.87 € /$ hour, respectively. It can be concluded that the single-drum hydraulic system, which is mounted on the front of the tractor, can be used as an alternative harvesting equipment especially for uphill winching operations in small scale forestry operations.
\end{abstract}

KEY WORDS: Mountainous forests, forest harvesting, farm tractor, productivity, whole-tree method, developing countries

\section{INTRODUCTION}

UVOD

Since the 1960s, it has become progressively accepted that, for a sustainable management, several criteria have to be considered at the same time. The consequence is that the decision-makers need a suitable multi-criteria decisionmaking methodologies (Erler 2017). The use of forest re- sources and production of forest products vary according to the development level of the countries. This variation is primarily observed in planning and implementation of timber extraction methods due to relatively high proportion of economic benefits provided by wood-based forest products in forest industry. In some countries, forest products are being produced for a limited number of industrial uses by utilizing limited amount of mechanization involvement. 
The selection of a harvesting system is mainly reflected by the supply and demand of forest products in the forest industry. Besides, there are natural factors such as topographical conditions and terrain types that effect the selection of mechanized harvesting equipment used in forestry (Visser and Berkertt 2015). In Eastern Black Sea region of Turkey where topographical conditions are favorable and wide range of industrial wood-based forest products are available (Ozturk and Senturk 2016), hi-tech harvesting machinery are used in forest operations (Sessions 2007; Visser and Harill 2017). In the investments made to the machinery used for forestry operations, the harvesting managers prefer mechanized equipment with high cost efficiency, production rate, mobility, and ergonomic features (Đuka et al. 2018; Kulak et all 2017; Moskalik et al. 2017; Ozturk 2010; Russell and Mortimer 2005;).

In Turkey, the timber harvesting activities are mainly conducted by the forest villagers and forest development cooperatives. Due to limited economic conditions, high technology equipment is often out of reach and the most common harvesting methods are human-power based traditional methods with limited involvement of farm tractors. Farm tractors have been used in many other countries in the concept of small-scale forestry due to their affordability and adaptability (Akay 2005; Magagnotti and Spinelli 2011; Ozturk and Akay 2007). Especially modified farm tractors can perform several tasks in timber harvesting operations such as skidding, winching, cable yarding, forwarding, and loading (Acar and Unver 2012; Johansson 1996; 1997; Spinelli and Magagnotti 2011).

Previous studies indicated that skidding with farm tractor usually requires the average slope of $15 \%$ and the skidding distances of $30-70$ meters (Gilanipoor et al. 2012). The cable winching with farm tractors can be efficient at the skidding distances of $30-50$ meters with an average terrain slope of 25\% (Heinrich 1987). Spinelli et al. (2004) stated that the cost of using a farm tractor can be very high at the skidding distances between 150 and 500 meters. In Turkey, different types of farm tractors integrated with mounted winch system and skidding equipment have been
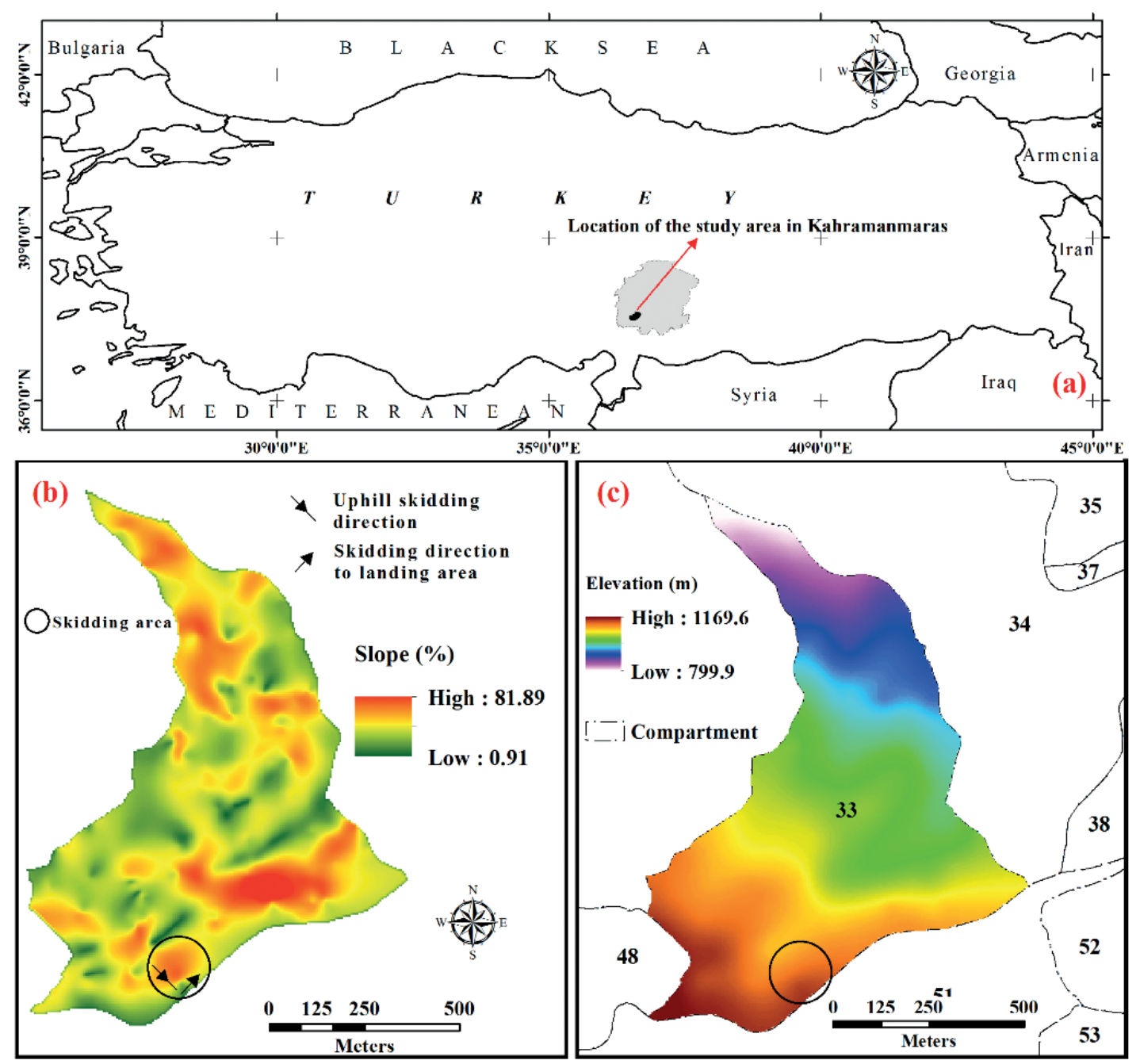

Figure 1. Geographic location of the study area $(a)$ and $(b-c)$ topographical data for the main study area Slika 1. Geografska lokacija područja istraživanja $(a)$ i $(b-c)$ topografski podaci za glavno područje istraživanja 
Table 1. The characteristics of used farm tractor (TUMOSAN 2018) Tablica 1. Značajke korištenog poljoprivrednog traktora (TUMOSAN 2018)

\begin{tabular}{|c|c|}
\hline $\begin{array}{l}\text { Manufacturer } \\
\text { Proizvođač }\end{array}$ & $\begin{array}{l}\text { TUMOSAN engine and } \\
\text { tractor Co., Turkey } \\
\text { TUMOSAN engine and } \\
\text { tractor Co, Turska }\end{array}$ \\
\hline Emission level & Stage IIIA (Tier 3) \\
\hline Razina emisija & Faza IIIA (razina 3) \\
\hline Number of cylinders / Aspiration & 4 / Turbo Intercooler \\
\hline Broj cilindara / Usis & 4/ turbo međurashladnik \\
\hline $\begin{array}{l}\text { Cylinder volume (It) } \\
\text { Zapremnina cilindra (I) }\end{array}$ & 3.9 \\
\hline $\begin{array}{l}\text { Nominal engine power (HP) } \\
\text { Nominalna snaga motora (KS) }\end{array}$ & 75 \\
\hline $\begin{array}{l}\text { Maximum torque (Nm) } \\
\text { Maksimalni okretni moment ( } \mathrm{Nm})\end{array}$ & 320 \\
\hline Transmission type & Four-wheel draft \\
\hline Vrsta prijenosa & Pogon na sva četiri kotača \\
\hline $\begin{array}{l}\text { Hydraulic power output } \\
\text { Hidraulična izlazna snaga }\end{array}$ & - \\
\hline $\begin{array}{l}\text { Load capacity (kg) } \\
\text { Dozvoljeno opterećenje (kg) }\end{array}$ & 2200 \\
\hline $\begin{array}{l}\text { Empty weight }(\mathrm{kg}) \\
\text { Težina praznog vozila }(\mathrm{kg})\end{array}$ & 3200 \\
\hline
\end{tabular}

studied in the timber extraction activities (Acar 2013). In some studies carried out in this context, it was determined that the skidding distance, slope, timber volume and number of logs are effective on the productivity of the farm tractor (Ozturk 2010). The additional equipment attached to the farm tractors for winching, forwarding or loading purposes may show different performances in terms of productivity of the system (Acar 1997). In recent years, examples of decision support systems have been developed in order to increase the productivity of the farm tractors in harvesting operations (Gumus and Turk 2016).

Modifications of farm tractors specially designed for forest operations have recently increased the attractiveness of farm tractors in the forest industry. There are considerable experiences in the use of farm tractors especially for smallscale forestry activities. As a result, the need to investigate the effectiveness and efficiency of the modified farm tractors has emerged in recent years. In this study, productivity of the farm tractor with front-mounted single drum winch was evaluated during whole-tree harvesting operation in Eastern Mediterranean region of Turkey.

\section{MATERIAL AND METHODS} MATERIJAL I METODA

\section{Study area - Područje istraživanja}

This study was carried out in Baskonus Forest Enterprise Chief (FEC) of Kahramanmaras Enterprise Directorate within the border of Kahramanmaras Regional Forest Di- rectorate in Eastern Mediterranean region of Turkey (Figure 1). The dominant tree species in the region are black pine (Pinus nigra Arn.), Turkish red pine (Pinus brutia Ten.), firs (Abies cilicica Ant. et Kotschy) and cedars (Cedrus libani L.). The average elevation in the main study area ranges from 800 meters to 1170 meters. Time study data were collected during timber extraction of Turkish red pine trees in compartment 33 (GDF 2012). The ground slope at the uphill winching area ranged between $45 \%$ and 50\% while the slope of skid trail was between 5\% and 10\% (Figure $1 \mathrm{~b}$ and $1 \mathrm{c})$.

\section{Field study - Istraživanje na terenu}

The geographic positional information was recorded by using a Global Positioning System (GPS). The topographical structure was determined by NRTK (Network Real Time Kinematic) Global Navigation Satellite System (GNSS)GPS surveyed digital terrain model were evaluated by using GIS techniques for the sensitive determination of trails' topographic attributes. Chronometers were used in time and work study. Besides, a digital camera was used to show the working area and the condition of the farm tractor during the winching and skidding stages. Total tree volume and cost information for stand compartment 33 was obtained from Kahramanmaras Regional Forest Directorate.

A four-wheel drive farm tractor equipped with 4-cylinder Turbo Intercooler system was used during timber extraction applications. The list price without taxes of operated farm tractor is approximately $17718 €$. Main of mechanical and hydraulic properties of the tractor are shown in Table 1. The timber extraction operation was carried out by four forest villagers who were employed by a forestry development cooperative. Forest villagers stated that they had more than five years of experience in performing forestry operations.

Using whole-tree method, felled trees were transported uphill from stump to skid trail by using single drum winch mounted in front of a farm tractor and then they were skidded on the skid trail while tractor was moving backward to the landing area (Figure 2).

The winch system was reinforced by an iron frame in order to prevent damage to the farm tractor during timber extraction. The thickness of used the steel rope, was $14 \mathrm{~mm}$. The maximum rope length capacity of drum was $80 \mathrm{~m}$. Tractor was equipped with a front protection blade which can move up and down by hydraulic pressure for stability purposes. Joystick arm type controllers were placed next to the tractor operator in the cabin for manual control of the hydraulic system (i.e. winch and blade). The cost including iron frame, front protection blade apparatus and hydraulic system of designed single drum winch was $1860 €$. 


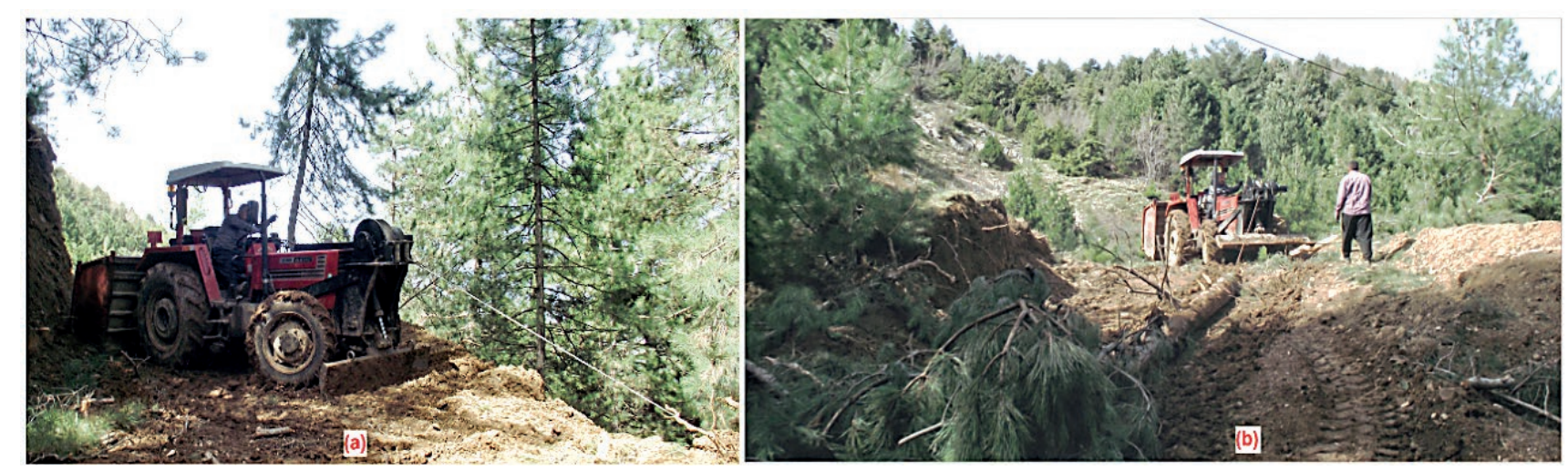

Figure 2. Timber extraction: uphill winching (a) and skidding backward on skid rail (b)

Slika 2. Privlačenje drva: privitlavanje uzbrdo (a) i privlačenje drva kretanjem unatrag (b)

\section{Time study and statistical analysis - Studija vremena i statistička obrada podataka}

The repetitive time method, which is also know as snapback method is one of the most common time study methods in forestry, (Eker and Acar 2014; Gulci et al. 2017a; Melemez et al. 2014; Proto et al. 2018; Spinelli and Magagnotti 2011) and was used in this study for analysis of system productivity. Time measurements were made during 30 trips for both uphill winching and skidding on skid trail. The main work stages for both operations are listed in Table 2. The time spent on resting, injuries, and other work-related delays were separated from other work stages (Björheden et al. 1995). Tree diameter and tree length data measured in the field were used to compute tree volume, and then productivity of each trip was calculated based on timber volume and total cycle time.

One-Way ANOVA, Pearson correlation test, and linear regression analysis were used for the analysis of the data obtained from time measurements. The differences between

Table 2. The main working stages

Tablica 2. Glavne faze rada

\begin{tabular}{|c|c|}
\hline Uphill winching & Skidding backward on skid trail \\
\hline Privitlavanje uzbrdo & \\
\hline Moving to the winching station & Moving to the prebunching area \\
\hline Premještanje na stanicu s vitlom & Premještanje na primarno sakupljalište \\
\hline $\begin{array}{l}\text { Pulling of steel rope to the felled } \\
\text { tree }\end{array}$ & Choker setting \\
\hline $\begin{array}{l}\text { Izvlačenje čeličnog užeta do } \\
\text { srušenog stabla }\end{array}$ & Namještanje kopče užeta \\
\hline Choker setting & Skidding backward \\
\hline Namještanje kopče užeta & Privlačenje drva kretanjem unatrag \\
\hline Winching to the prebunching area & Unhooking at the landing \\
\hline $\begin{array}{l}\text { Privitlavanje do primarnog } \\
\text { sakupljališta }\end{array}$ & Otkopčavanje tovara na stovarištu \\
\hline \multicolumn{2}{|l|}{$\begin{array}{l}\text { Unhooking at the prebunching } \\
\text { area }\end{array}$} \\
\hline $\begin{array}{l}\text { Otkopčavanje tovara na } \\
\text { primarnom sakupljalištu }\end{array}$ & \\
\hline
\end{tabular}

the averages in the study with equal number of samples were evaluated by the Tukey multiple comparison test ( $\mathrm{R}$ Core Team 2018; SPSS 2017). For both operations (phases), the effects of tree volume on productivity was investigated by using ANOVA at the 0.05 significance level. Tree volume extracted in each trip was divided in to three classes including low $\left(<0.40 \mathrm{~m}^{3}\right)$, medium $\left(0.41-0.80 \mathrm{~m}^{3}\right)$, and high $\left(>0.80 \mathrm{~m}^{3}\right)$. Pearson correlation test was applied to determine the relationship between tree diameter $\left(\mathrm{X}_{1}\right)$, length $\left(\mathrm{X}_{2}\right)$, volume $\left(\mathrm{X}_{3}\right)$, and skidding distance $\left(\mathrm{X}_{4}\right)$ and total time (Y). Finally, Linear Regression Analysis was used to determine the mathematical models of total cycle time for wholetree extraction methods.

\section{RESULTS AND DISCUSSIONS REZULTATI I RASPRAVA}

Productivity of the farm tractor was determined during whole tree uphill winching and skidding backward by using time study method. The same trees extracted from the harvesting unit were transported during both working semi-phases. The average tree volume transported in each trip was $0.64 \mathrm{~m}^{3}$. The average winching distance and skidding distance were to be 30 meters and 91 meters respectively. The ground slope at uphill winching area and on a skid trail was $49 \%$ and $7 \%$, respectively.

\section{Productivity analysis - Analiza proizvodnosti}

The average time study data for each work stage in uphill winching is indicated in Table 3 . The results indicate that winching trees to the prebunching area was the most time consuming work stage (49\%), followed by pulling steel rope to the fallen tree (23\%) and moving to the winching station (22\%). In a previous study, it was reported that the most time consuming work stage during winching whole-trees by farm tractor was again winching trees to roadside landing (40\%) (Gulci 2014). 
Table 3. Time study data (minutes) for work stages in whole-tree uphill winching

Tablica 3. Podatci studije vremena tijekom privitlavanja drva uzbrdo

\begin{tabular}{|c|c|c|c|c|}
\hline $\begin{array}{l}\text { Work Stages } \\
\text { Faze rada }\end{array}$ & $\begin{array}{l}\text { Min. } \\
\text { Min. }\end{array}$ & $\begin{array}{l}\text { Max. } \\
\text { Maks. }\end{array}$ & $\begin{array}{l}\text { Average } \\
\text { Prosjek }\end{array}$ & $\begin{array}{c}\text { Std. } \\
\text { Deviation } \\
\text { Standardna } \\
\text { devijacija }\end{array}$ \\
\hline $\begin{array}{l}\text { Moving to the winching station } \\
\text { Premještanje na stanicu s vitlom }\end{array}$ & 0.48 & 1.13 & 0.76 & 0.24 \\
\hline $\begin{array}{l}\text { Pulling steel rope to the fallen tree } \\
\text { Izvlačenje čeličnog užeta do } \\
\text { srušenog stabla }\end{array}$ & 0.21 & 1.55 & 0.79 & 0.46 \\
\hline $\begin{array}{l}\text { Choker setting } \\
\text { Kopčanje tovara }\end{array}$ & 0.07 & 0.16 & 0.13 & 0.03 \\
\hline $\begin{array}{l}\text { Winching to the prebunching area } \\
\text { Privitlavanje do primarnog } \\
\text { sakupljališta }\end{array}$ & 0.64 & 3.50 & 1.70 & 0.95 \\
\hline $\begin{array}{l}\text { Unhooking at the prebunching area } \\
\text { Otkopčavanje tovara na primarnom } \\
\text { sakupljalištu }\end{array}$ & 0.05 & 0.08 & 0.07 & 0.01 \\
\hline $\begin{array}{l}\text { Total Time } \\
\text { Ukupno vrijeme }\end{array}$ & 1.52 & 5.87 & 3.44 & 1.36 \\
\hline
\end{tabular}

It was found that the average productivity of uphill winching was calculated as $12.98 \mathrm{~m}^{3} /$ hour. In a previous study where the uphill winching was performed by a farm tractor, it was stated that the average productivity was $5.05 \mathrm{~m}^{3} /$ hour for a stand with $0.20 \mathrm{~m}^{3}$ timber volume, winching distance of 30 meters, and ground slope of $45 \%$ (Gulci 2014). Therefore, average timber volume transported in each trip dramatically effects the productivity of the winching operation, when distance is constant.

For skidding the average time study data for each work stage is indicated in Table 4. It was found that skidding trees while moving backward to landing was the most time consuming work stage (64\%), followed by moving to the prebunching area (23\%). In a similar study where farm tractor was used for skidding, it was found that the most time consuming work stage was skidding loaded to landing area (46\%), followed by moving to the roadside (Gilanipoor et al. 2012).
The average productivity of skidding trees by farm tractor on skid trail was $14.30 \mathrm{~m}^{3} /$ hour. Gulci et al. (2017b) reported that the productivity of farm tractor in skidding whole-tree was $13.50 \mathrm{~m}^{3} /$ hour in a stand with average skidding distance of 80 meters and $20 \%$ skid trail slope. Thus, slope of the skid trail is one of the main factors that affects productivity. The skidding distance is other important factor on operation time which reflects the overall productivity (Borz et al. 2015; Đuka et al. 2017; Gilanipoor et al. 2012). On the other hand, undoubtedly terrain conditions and operator experiences also influence the productivity of harvesting methods (Mousavi and Naghdi 2014).

The results show that different volume classes have significant $(\mathrm{p}<0.01)$ effects on productivity in both working phases (winching and skidding). The average productivity for uphill winching increased from low volume class to medium and high volume classes (Table 5, Table 6). Previous studies conducted on forest operations also indicated that efficiency of the system increases as the timber volume per trip increases (Gulci et al. 2017b; Ozturk and Akay 2007;

Table 4. Time study data (minutes) for work stages in skidding backward on skid trail

Tablica 4. Podaci studije vremena (minute) tijekom privlačenja drva kretanjem unatrag po traktorskoj vlaki

\begin{tabular}{|c|c|c|c|c|}
\hline $\begin{array}{l}\text { Work Stages } \\
\text { Faze rada }\end{array}$ & $\begin{array}{l}\text { Min. } \\
\text { Min. }\end{array}$ & $\begin{array}{l}\text { Max. } \\
\text { Maks. }\end{array}$ & $\begin{array}{l}\text { Average } \\
\text { Prosjek }\end{array}$ & $\begin{array}{l}\text { Std. } \\
\text { Deviation } \\
\text { Standardna } \\
\text { devijacija }\end{array}$ \\
\hline $\begin{array}{l}\text { Moving to the prebunching area } \\
\text { Premještanje na primarno } \\
\text { sakupljalište }\end{array}$ & 0.54 & 1.15 & 0.77 & 0.25 \\
\hline $\begin{array}{l}\text { Choker setting } \\
\text { Kopčanje tovara }\end{array}$ & 0.07 & 0.16 & 0.13 & 0.03 \\
\hline $\begin{array}{l}\text { Skidding backward } \\
\text { Privlačenje drva kretanjem unatrag }\end{array}$ & 1.16 & 3.01 & 1.72 & 0.52 \\
\hline $\begin{array}{l}\text { Unhooking at the landing } \\
\text { Otkopčavanje tovara na stovarištu }\end{array}$ & 0.05 & 0.09 & 0.07 & 0.01 \\
\hline $\begin{array}{l}\text { Total Time } \\
\text { Ukupno vrijeme }\end{array}$ & 1.93 & 4.36 & 2.68 & 0.77 \\
\hline
\end{tabular}

Table 5. Statistical analysis results for uphill winching

Tablica 5. Statistička obrada podataka za privitlavanje drva uzbrdo

\begin{tabular}{|c|c|c|c|c|c|c|c|c|}
\hline \multirow{2}{*}{$\begin{array}{c}\text { Volume } \\
\text { Classes } \\
\text { Klase obujma }\end{array}$} & \multirow[t]{2}{*}{$\mathrm{N}$} & \multirow{2}{*}{$\begin{array}{l}\text { Mean } \\
\text { Srednja } \\
\text { vrijednost }\end{array}$} & \multirow{2}{*}{$\begin{array}{l}\text { Std. Deviation } \\
\text { Std devijacija }\end{array}$} & \multirow{2}{*}{$\begin{array}{l}\text { Std. Error } \\
\text { Std greška }\end{array}$} & $\begin{array}{r}95 \% \text { Confidence } \\
95 \% \text { interval } \\
\text { srednju }\end{array}$ & $\begin{array}{l}\text { iterval for Mean } \\
\text { uzdanosti za } \\
\text { ijednost }\end{array}$ & Min. & \multirow{2}{*}{$\begin{array}{l}\text { Max. } \\
\text { Maks. }\end{array}$} \\
\hline & & & & & $\begin{array}{l}\text { Lower Bound } \\
\text { Donja granica }\end{array}$ & $\begin{array}{l}\text { Upper Bound } \\
\text { Gornja granica }\end{array}$ & & \\
\hline $\begin{array}{l}\text { Low } \\
\text { Mali }\end{array}$ & 9 & 3.31 & 1.06 & 0.35 & 2.49 & 4.12 & 2.14 & 5.33 \\
\hline $\begin{array}{l}\text { Medium } \\
\text { Srednji }\end{array}$ & 12 & 11.88 & 5.56 & 1.61 & 8.34 & 15.41 & 4.50 & 21.59 \\
\hline $\begin{array}{l}\text { High } \\
\text { Visoki }\end{array}$ & 9 & 24.13 & 12.41 & 4.14 & 14.59 & 33.67 & 11.93 & 43.76 \\
\hline $\begin{array}{l}\text { Total } \\
\text { Ukupno }\end{array}$ & 30 & 12.98 & 11.08 & 2.02 & 8.85 & 17.12 & 2.14 & 43.76 \\
\hline
\end{tabular}


Table 6. Statistical analysis results for skidding backward on skid trail

Tablica 6. Statistička obrada podataka za privlačenje drva kretanjem unatrag po traktorskoj vlaci

\begin{tabular}{|c|c|c|c|c|c|c|c|c|}
\hline \multirow{2}{*}{$\begin{array}{l}\text { Volume } \\
\text { classes } \\
\text { Klase obujma }\end{array}$} & \multirow[t]{2}{*}{$\mathrm{N}$} & \multirow{2}{*}{$\begin{array}{l}\text { Mean } \\
\text { Srednja } \\
\text { vrijednost }\end{array}$} & \multirow{2}{*}{$\begin{array}{l}\text { Std. Deviation } \\
\text { Std devijacija }\end{array}$} & \multirow{2}{*}{$\begin{array}{l}\text { Std. Error } \\
\text { Std greška }\end{array}$} & \multicolumn{2}{|c|}{$\begin{array}{l}\text { 95\% Confidence Interval for Mean } \\
\text { 95\% interval pouzdanosti za } \\
\text { srednju vrijednost }\end{array}$} & \multirow{2}{*}{$\begin{array}{l}\text { Min. } \\
\text { Min. }\end{array}$} & \multirow{2}{*}{$\begin{array}{l}\text { Max. } \\
\text { Maks. }\end{array}$} \\
\hline & & & & & $\begin{array}{l}\text { Lower Bound } \\
\text { Donja granica }\end{array}$ & $\begin{array}{l}\text { Upper Bound } \\
\text { Gornja granica }\end{array}$ & & \\
\hline $\begin{array}{l}\text { Low } \\
\text { Mali }\end{array}$ & 9 & 6.06 & 2.41 & 0.80 & 4.21 & 7.91 & 3.12 & 9.31 \\
\hline $\begin{array}{l}\text { Medium } \\
\text { Srednji }\end{array}$ & 12 & 11.40 & 3.57 & 1.03 & 9.14 & 13.67 & 7.10 & 17.01 \\
\hline $\begin{array}{l}\text { High } \\
\text { Visoki }\end{array}$ & 9 & 26.39 & 14.42 & 4.81 & 15.31 & 37.48 & 14.22 & 51.30 \\
\hline $\begin{array}{c}\text { Total } \\
\text { Ukupno }\end{array}$ & 30 & 14.30 & 11.56 & 2.11 & 9.98 & 18.61 & 3.12 & 51.30 \\
\hline
\end{tabular}

Spinelli and Magagnotti 2011). Today, because of the developments in engine and hydraulic technologies, farm tractors modified for performing forest operations potentially provide higher production rate. In addition, well trained operators with sufficient experience, knowledge and skills are the key for high productivity in harvesting operations (Enache et al. 2016).

\section{Statistical models - Statistički modeli}

According to the Pearson correlation test results, it was determined that there was a significant relationship between the distance $\left(\mathrm{X}_{4}\right)$ and the total time $(\mathrm{Y})$ at the $99 \%$ confidence level ( $\mathrm{p}: 0.00, \mathrm{p}<0.01$ ) for both methods (Figure 3). There was no significant relationship in the $95 \%$ confidence interval ( $p>0.05)$ between the variables of diameter $\left(X_{1}\right)$ (p: 0.352), length $\left(\mathrm{X}_{2}\right)$ (p: 0.974) and volume $\left(\mathrm{X}_{3}\right)(\mathrm{p}: 0.635)$ and total time $(\mathrm{Y})$ for uphill winching. There was a significant relationship between the volume $\left(\mathrm{X}_{3}\right)(\mathrm{p}$ : 0.045) and the total time $(Y)$ for $95 \%$ confidence level $(p<0.05)$ for skidding.

As a result of comparing the possible combination of decision variables, the best linear model was considered by using corrected Akaike information criterion (AICc), Bayesian information criterion (BIC) and $\mathrm{R}^{2}$. Then it was decided to add all of decision variables $\left(\mathrm{X}_{1}, \mathrm{X}_{2}, \mathrm{X}_{3}\right.$ and $\left.\mathrm{X}_{4}\right)$ in the model. The $\mathrm{R}^{2}$ values of the regression models of uphill winching and skidding on skid trail were found to be 0.896 (AICc: 51.46, BIC: 56.21) and 0.980 (AICc: -31.43, BIC:

\section{(a)}

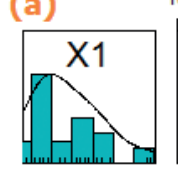

$\begin{array}{llll}10 & 15 & 20 & 25\end{array}$
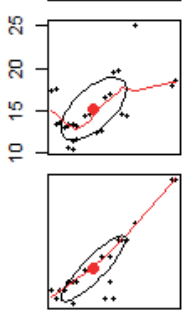

은
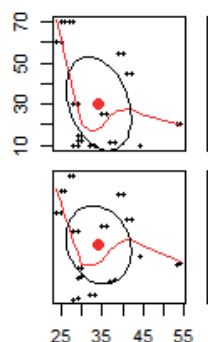
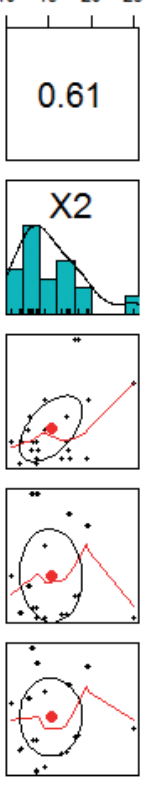
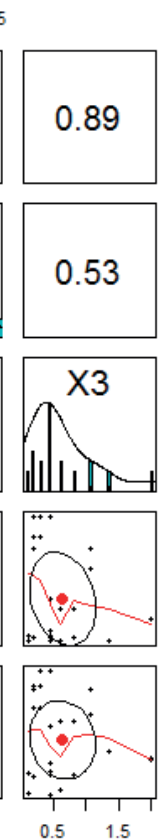

$\begin{array}{llll}10 & 30 & 50 & 70\end{array}$
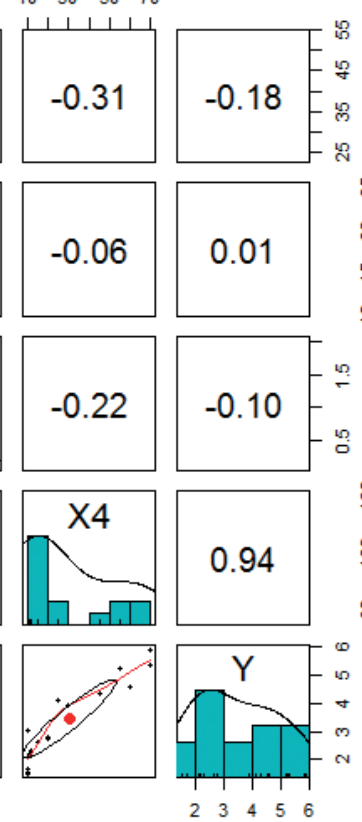

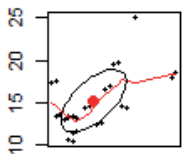

(b)

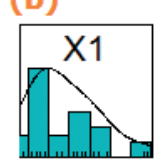

$\begin{array}{llll}10 & 15 & 20 & 25\end{array}$

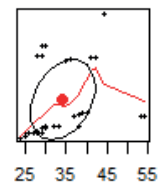

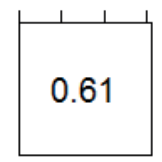
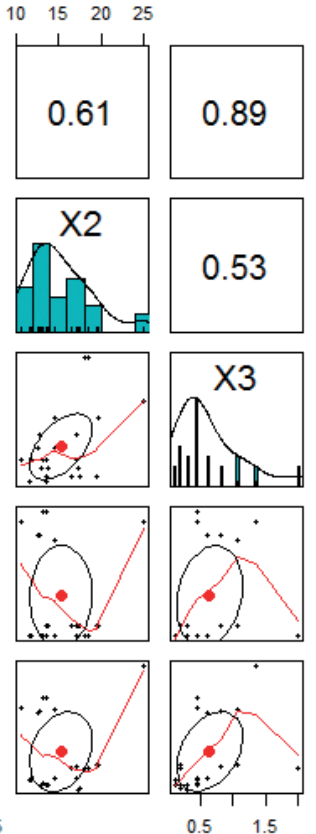

$\begin{array}{lll}60 & 120 \quad 180\end{array}$
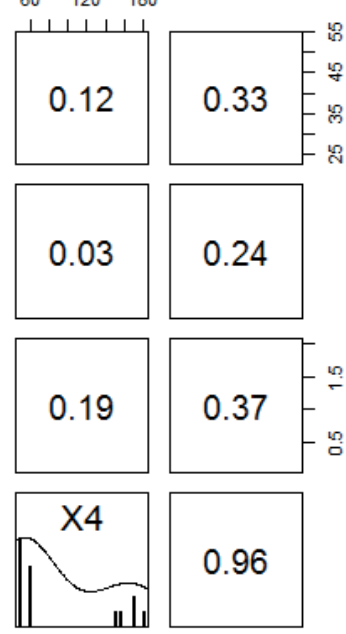

0.96

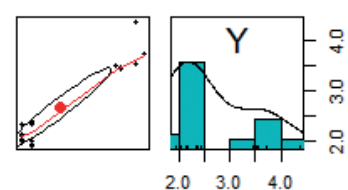

Figure 3. Results of Pearson correlation tests for uphill winching (a) and skidding backward (b)

Slika 3. Rezultati testa Pearsonov korelacije za privitlavanje uzbrdo (a) i privlačenje drva kretanjem unatrag (b) 

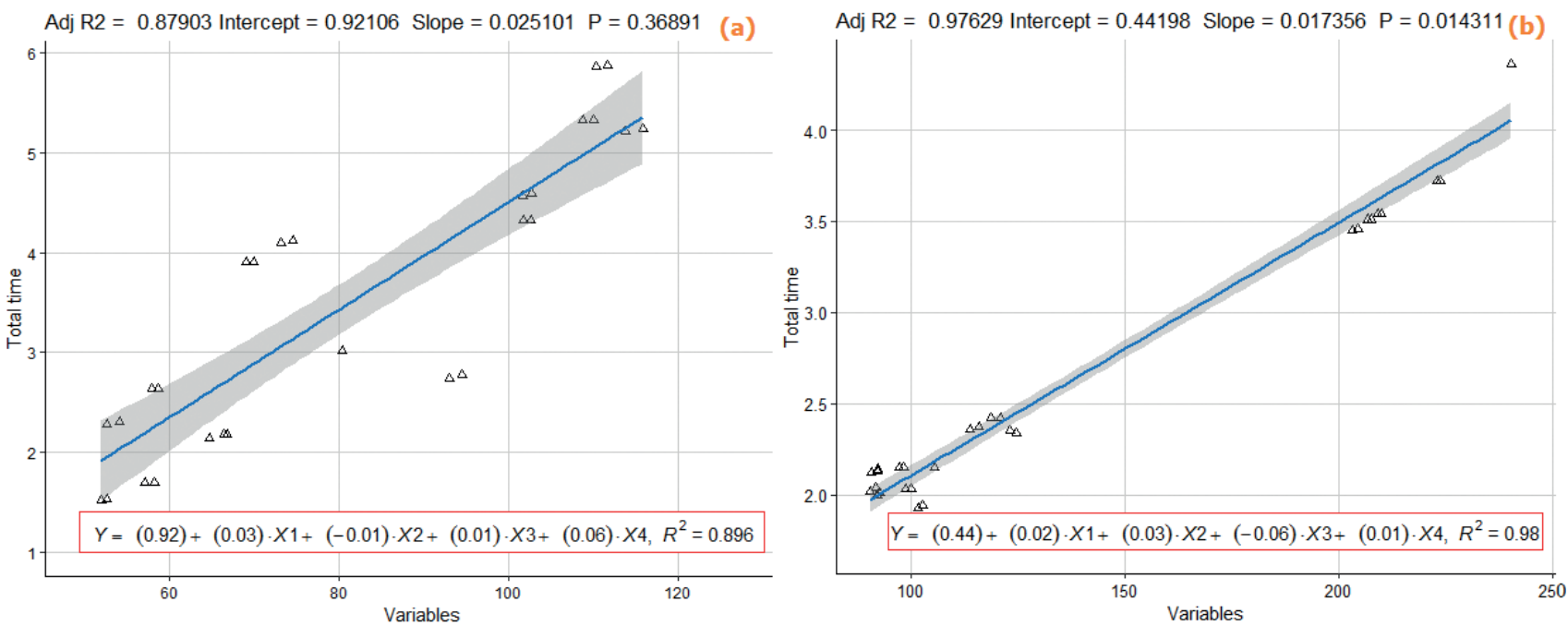

Figure 4. Parameters of a regression model (a: uphill winching and b: skidding backward)

Slika 4. Parametri regresijskog modela (a: privitlavanje uzbrdo i b: privlačenje drva kretanjem unatrag)

-26.68), respectively. The regression model yielded significant $(\mathrm{p}<0.01)$ results at $99 \%$ confidence level in both methods. The regression analysis results for the variables of diameter $\left(\mathrm{X}_{1}\right)$, length $\left(\mathrm{X}_{2}\right)$, volume $\left(\mathrm{X}_{3}\right)$ and skidding distance $\left(\mathrm{X}_{4}\right)$ are given in Figure 4.

\section{CONCLUSIONS} ZAKLJUČCI

Farm tractors equipped with winches have been widely used as effective equipment in small-scale forestry activities in many countries. In timber extraction with farm tractors in Turkey, the drum is often mounted on the back of the tractor. In this study, productivity of the farm tractor with front-mounted single drum winch was evaluated during whole-tree harvesting operations. In the field, fallen trees were first winched uphill from stump to the prebunching area by using single drum winch and then trees were transported backward to the landing area. The factors that affect the productivity of both working phases (winching and skidding) were evaluated. The average daily productivity of uphill winching and skidding whole-trees was at $103.84 \mathrm{~m}^{3} / 8$-hours and $114.40 \mathrm{~m}^{3} / 8$-hours, respectively. Besides, the average daily cost of uphill winching and skidding whole-trees was at $86.18 € / 8$-hours and $94.97 € / 8$-hours, respectively. According to the results, the average daily cost of skidding whole-trees was required $8.79 € / 8$-hours higher than the average daily cost of uphill winching.

A single drum winch system mounted in front of farm tractor can be considered as a very efficient alternative equipment for uphill winching operations depending on the ability of the operator. The stable position of the tractor is ensured by a movable front protection blade prevents uncontrolled shifting of the tractor and ensures ergonomic and safe operations. The productivity of skidding operation on skid trail was relatively low comparing with the results of the relevant studies. The main reason behind this inefficiency was that operator had to drive the skidder backward on skid trail and control the back sight which increased the total time during skidding. Farm tractor logging can be also limited by some other factors such as the terrain conditions, ground slope, and timber volume. Thus, the capabilities of the farm tractors and functionalities of the additional attachments should be well understood before performing an effective farm tractor logging operations. To improve the efficiency, effective logging plan should be made to ensure physically feasible and economically viable operations.

\section{ACKNOWLEDGEMENTS}

\section{ZAHVALA}

This paper includes data from Kahramanmaras Sutcu Imam University Scientific Research Project (No: 2016/3$72 \mathrm{M})$. The author would like to thank Nihat Nurdoğan (Forest Enterprise Chief of Baskonus) and anonymous forest workers for their help in field work.

\section{REFERENCES}

\section{LITERATURA}

- Acar, H.H., 1997: An investigation on the extraction from compartment by tractors at the mountainous region, Turk J Agric For, 21: 299-306.

- Acar, H.H., S. Unver, 2012: Working efficiency during the controlled sliding of logs in the polyethylene chute by tractor power, SDU Faculty of Forestry Journal, 13(2): 97-102.

- Acar, H.H., 2013: Assessment of unit work time in logging operations the using of log pulling-sliding head during cable skid- 
ding of the logs by tractor power on steep terrain, Kastamonu Univ., Journal of Forestry Faculty, 13(1): 144-152.

- Akay, A.E., 2005: Using farm tractors in small-scale forest harvesting operations, J App Sci Res, 1(2): 196-199.

- Björheden, R., K. Apel, M. Shiba, M.A. Thompson, 1995: IUFRO forest work study nomenclature, Swedish University of Agricultural Science, Dept. of Operational Efficiency, p.16. Garpenberg.

- Borz, S.A., G. Ignea, B. Popa, G. Spârchez, E. Iordache, 2015: Estimating time consumption and productivity of roundwood skidding in group shelterwood system-a case study in a broadleaved mixed stand located in reduced accessibility conditions, Croat J For Eng, 36(1): 137-146.

- Đuka, A., S. Grigolato, I. Papa, T. Pentek, T. Poršinsky, 2017: Assessment of timber extraction distance and skid road network in steep karst terrain. iForest, 10(6): 886-894. doi:10.3832/ ifor2471-010

- Đuka, A., T. Poršinsky, T. Pentek, Z. Pandur, D. Vusić, I. Papa, 2018: Mobility range of a cable skidder for timber extraction on sloped terrain. Forests, 9(9): 526, doi: 10.3390/f9090526

- Eker, M., H.H. Acar, 2014: Assessment of unit work time in logging operations, II. Mediterranean Forest and Environment Symposium, p. 291-299, Isparta.

- Enache, A., M. Kühmaier, R. Visser, K. Stampfer, 2016: Forestry operations in the European mountains: a study of current practices and efficiency gaps, Scand J Forest Res, 31(4): 412-427.

- Erler, J., 2017: Transfer system to adapt timber harvesting operations to local conditions. Croat J For Eng, 38(2), 197-208.

- GDF (General Directorate of Forestry)., 2012: Forest management plans and maps of Baskonus Enterprise Chief (between 2012 - 2021 years), Available in https://www.ogm.gov.tr/ekutuphane/default.aspx. Accessed: 12 March 2018.

- Gilanipoor, N., A. Najafi, S.M. Heshmat Alvaezin, 2012: Productivity and cost of farm tractor skidding, J For Sci, 58(1): 2126.

- Gulci, N., 2014: Researches on precision forestry in forest planning, Dissertation (PhD thesis), Faculty of Forestry, Kahramanmaras, Turkey, 264 p. [Turkish]

- Gulci, N., A.E. Akay, O. Erdas, H.H. Acar, 2017a: Productivity analysis of chute system integrated with portable winch and synthetic rope for uphill logging operation, Eur J Forest Eng, 3(2): 72-77.

- Gulci, N., S. Gulci, A.E. Akay, 2017b: Productivity analysis of skidding operations with farm tractor on skid roads: The case of Osmaniye forest enterprise chief, Turkey, Innovating the Competitive Edge: From Research to Impact in the Forest Value Chain, FORMEC, 124-129. Brasov.

- Gumus, S., Y. Turk, 2016: A new skid trail pattern design for farm tractors using linear programing and geographical information systems, Forests, 7(12): 306-316.

- Heinrich, R., 1987: Appropriate wood harvesting applying farm tractors in skidding and forwarding operations in plantation forest in developing operations. Food and Agriculture Organization of United Nations. Forestry Paper 78. p. 266, Rome.

- Johansson, J., 1996: Case studies on farm tractors as base machines for single-grip thinning harvester heads, Forestry 69(3): 229-244.

- Johansson, J., 1997: Small tree harvesting with a farm tractor and crane attached to the front, Journal of Forest Engineering, $8(1): 21-33$.
- Kulak, D., A. Stańczykiewicz, G. Szewczyk, 2017: Productivity and time consumption of timber extraction with a grapple skidder in selected pine stands. Croat J For Eng, 38(1): 55-63.

- Magagnotti, N., R. Spinelli, 2011: Financial and energy cost of low-impact wood extraction in environmentally sensitive areas, Ecol Eng, 37(4): 601-606.

- Melemez, K., M. Tunay, T. Emir, 2014: A comparison of productivity in five small-scale harvesting systems, Small-scale For, 13(1): 35-45.

- Moskalik, T., S.A. Borz, J. Dvořák, M. Ferencik, S. Glushkov, P. Muiste, A. Lazdiņš, O. Styranivsky, 2017: Timber harvesting methods in eastern European countries: A review. Croat J For Eng, 38(2): 231-241.

- Mousavi, R., R. Naghdi, 2014: Comparison of productivity and cost of timber extraction by farm tractor, skidding vs. forwarding in Northern Iran, HortFlora Research Spectrum, 3(3): 201210 .

- Ozturk, T., A.E. Akay, 2007: Modifying farm tractors for forest harvesting operations, Bottlenecks, Solutions, and Priorities in the Context of Functions of Forest Resources, 17-19 October. p. 1111-1120. Istanbul.

- Ozturk, T., 2010: Productivity of New Holland farm tractor at beech stands on mountainous areas in Black Sea Region, Forestry Ideas, 16(1): 52-57.

- Ozturk, T., N Senturk, 2016: Productivity and costs of timber extraction by Urus miii skyline yarder in Northeast Turkey. Sumar list, 140(11-12): 561-566.

- Proto, A.R., G. Macrì, R. Visser, D. Russo, G. Zimbalatti, 2018: Comparison of timber extraction productivity between winch and grapple skidding: A case study in Southern Italian forests, Forests, 9(2): 61-72.

- R Core Team., 2018: R: A language and environment for statistical computing ( $\mathrm{R}$ version 3.5.2.). R Foundation for Statistical Computing, Vienna, Austria. http://www.R-project.org/.

- Russell, F., D. Mortimer, 2005: A review of small-scale harvesting systems in use worldwide and their potential application in Irish forestry, COFORD, p. 56, Dublin.

- Sessions, J., 2007: Appropriate harvesting technology, In: Sessions, J. (Ed) Harvesting operations in the tropics, SpringerVerlag Berlin Heidelberg, p. 155-158.

- Spinelli, R., P.M. Owende, S.M. Ward, M. Tornero, 2004: Comparison of short-wood forwarding systems used in Iberia, Silva Fenn, 38(1): 85-94.

- Spinelli, R., N. Magagnotti, 2011: The effects of introducing modern technology on the financial, labour and energy performance of forest operations in the Italian Alps, Forest Policy Econ, 13(7): 520-524

- SPSS., 2017: IBM SPSS Statistics 15 Core System User's Guide, 426 p. Chicago, USA.

- TUMOSAN., 2018: Specification of farm tractor, Available in http://www.tumosan.com.tr/tr/urun/8075. Accessed 20 April 2018.

- Visser, R., H. Berkett, 2015: Effect of terrain steepness on machine slope when harvesting, International Journal of Forest Engineering, 26(1): 1-9.

- Visser, R., H. Harill, 2017: Cable yarding in North America and New Zealand: A review of developments and practices, Croat J For Eng, 38(2): 209-217. 


\section{SAŽETAK}

U pošumljenim područjima s nedostupnim terenom troškovi pridobivanja drva izrazito su važni. To utječe na razinu mehaniziranosti u šumarstvu. Adaptirani poljoprivredni traktori u širokoj su uporabi, posebice u zemljama u razvoju, kao učinkova sredstva za prijevoz trupaca ili debla od mjesta sječe do stovarišta. U ovom istraživanju procijenjena je proizvodnost adaptiranog poljoprivrednog traktora s jednobubanjskim vitlom smještenim s prednje strane vozila. Ukupni troškovi tog sustava (traktora i vitla) iznose otprilike $19580 €$ (Eura). Primijenjena je studija rada i vremena povratnom metodom tijekom dvofazne operacije privlačenja drva. Ispitani su učinci glavnih čimbenika kao što su promjer, visina, obujam i udaljenost privlačenja drva na ukupno vrijeme rada te je napravljena linearna regresijska analiza kako bi se razvio matematički model privlačenja drva. Podaci iz studije vremena pokazali su da privitlavanje debla do primarnog sakupljališta zahtijeva najviše vremena tijekom samog privitlavanja drva uzbrdo, dok je privlačenje debla do stovarišta zahtijevalo najviše vremena tijekom privlačenja drva općenito. Prosječna je proizvodnost sakupljanja drva uz nagib $12.98 \mathrm{~m}^{3} / \mathrm{sat}$, a privlačenje drva kretanjem unatrag $14.30 \mathrm{~m}^{3} / \mathrm{sat}$. Troškovi sakupljanja drva vitlom uz nagib iznose $10.77 € /$ sat, a privlačenje drva $11.87 € /$ sat. Može se zaključiti da se hidraulički sustav s jednobubanjskim vitlom, postavljen s prednje strane adaptiranog poljoprivrednog traktora, može koristiti kao alternativna oprema za pridobivanje drva, posebice kod operacija privitlavanja uzbrdo.

KLJUČNE RIJEČl: planinske šume, pridobivanje drva, poljoprivredni traktor, proizvodnost, stablovna metoda, zemlje u razvoju 